\title{
Improving the groundwater-well siting approach in consolidated rock in Nampula Province, Mozambique
}

\author{
F. J. Chirindja ${ }^{1,2} \cdot$ T. Dahlin ${ }^{2}$ D. Juizo ${ }^{1}$
}

Received: 17 June 2016 / Accepted: 6 January 2017 / Published online: 3 February 2017

(C) The Author(s) 2017. This article is published with open access at Springerlink.com

\begin{abstract}
Vertical electrical sounding was used for assessing the suitability of the drill sites in crystalline areas within a water supply project in Nampula Province in Mozambique. Many boreholes have insufficient yield $(<600 \mathrm{~L} / \mathrm{h})$. Electrical resistivity tomography (ERT) was carried out over seven boreholes with sufficient yield, and five boreholes with insufficient yield, in Rapale District, in an attempt to understand the reason for the failed boreholes. Two significant hydrogeological units were identified: the altered zone (19-220 ohm-m) with disintegrated rock fragments characterized by intermediate porosity and permeability, and the fractured zone $(>420$ ohm-m) with low porosity and high permeability. In addition to this, there is unfractured nonpermeable intact rock with resistivity of thousands of ohm-m. The unsuccessful boreholes were drilled over a highly resistive zone corresponding to fresh crystalline rock and a narrow altered layer with lower resistivity. Successful boreholes were drilled in places where the upper layers with lower resistivity correspond to a welldeveloped altered layer or a well-fractured basement. There are a few exceptions with boreholes drilled in seemingly favourable locations but they were nevertheless unsuccessful boreholes for unknown reasons. Furthermore, there were boreholes drilled into very resistive zones that produced successful water wells, which may be due to narrow permeable fracture zones that are not resolved by ERT. Community involvement is proposed, in choosing between alternative borehole locations based on information acquired with a scientifically based approach, including conceptual geological
\end{abstract}

F. J. Chirindja

farisse.chirindja@tg.lth.se

Eduardo Mondlane University, Maputo, Mozambique

2 Lund University, Lund, Sweden models and ERT. This approach could probably lower the borehole failure rate.

Keywords Vertical electrical sounding · Electrical resistivity tomography · Groundwater exploration · Crystalline rocks . Mozambique

\section{Introduction}

For water supply projects in rural areas, groundwater is often the main water source because it is often ready to be used without any treatment (Macdonald and Calowb 2009); however, in consolidated rock areas, the aquifers often have low hydraulic yield and dry wells occur (Kellett et al. 2004). The consequence is a waste of time and resources and projects may be repeated in areas already included in previous water supply projects instead of extending to new areas that have not benefited previously. For example, the Integrated Water Supply and Sanitation Project for Nampula and Niassa Provinces (ASNANI) and Cabo Delgado and Nampula Rural Water Point Installation (CDNRWPI) program in Mozambique are two drilling projects implemented in the same communities in Nampula province. Based on the value of the yield, a borehole is either considered to be successful if it has a yield higher than $900 \mathrm{~L} / \mathrm{h}$ or unsuccessful (failed) if the yield is lower. In both programs the reported unsuccessful or failure rate was between 25 to $35 \%$ (Salomon Lda, "Design report No. 2 for 250 water points". Internal unpublished report submitted to "Millenium Challenge Account - Mozambique and the National Directorate of Water/Rural Water Department', 2010; hereafter referred to as "Salomon Lda, unpublished report, 2010"). The failure is reportedly related to geology, i.e. in unconsolidated rock areas the drilling success is higher compared to consolidated rock areas (Clark 
1985; Salomon Lda unpublished report 2010). This research will focus only in consolidated rock areas based on the result of the CDNRWPI project.

The approach used in the CDNRWPI project was that each community indicated three different sites of their preference. Regarding the location of a new well, the geophysical investigations were carried out at these three sites to indicate the most favourable location for groundwater extraction. The investigation method chosen was vertical electrical sounding (VES), which assumes only vertical variation of the resistivity in the ground.

However in fractured and weathered consolidated rock areas, the lateral variation is often so strong that VES can be expected to give insufficient or even misleading results and ambiguities (Acworth 2001; Kellett et al. 2004; Kumar et al. 2007). Electrical resistivity tomography (ERT) can help to identify geological units and variation within lithological units which are highly significant with respect to groundwater in consolidated rock areas (Owen et al. 2005; Kumar 2012). ERT has been used to investigate groundwater in consolidated rock areas by many authors. Shemang and Chaoka (2003) investigated basement aquifer in Botswana, whereas Owen et al.(2005) and Muchingami et al.(2012) have investigated the groundwater in greenstone belt areas in Zimbabwe. In addition it is recommended that the magnetic resonance sounding (MRS) method, which detects free water content in the subsurface (Legchenko and Valla 2002), is used together with ERT (Vouillamoz et al. 2007) to reduce the uncertainties.

The aim of this study is to test whether the combination of both ERT and MRS methods can identify the reason of failure of groundwater wells sited based on investigation by VES. This is done by comparing the resulting geophysical models of unsuccessful boreholes with the models of successful boreholes; furthermore, the role of community choosing a favourable site is also discussed.

\section{Background}

\section{Geological and hydrogeological setting}

Mozambique is divided into two main geological structural regions, a Phanerozoic region and a Precambrian basement. The Precambrian basement is further divided into Archean cratonic units, Archean mobile belts and Proterozoic Units (Lächelt 2004). The Proterozoic Units consist of metamorphic rocks, quartzites, schists and gneisses along with interference of eruptive rock and dolerites. The rocks underwent pervasive tectonic reworking during the late Neoproterozoic collision orogeny at ca $550 \mathrm{Ma}$, known as the pan-African orogeny (Lächelt 2004). The eruptive rocks are weakly deformed Cambrian granites and granitoids with ages ranging from 514 to $504 \mathrm{Ma}$ (Macey et al. 2013). The coastal area is constituted by post-Cambrian sedimentary rocks and Quaternary alluvial sand formations (Lächelt 2004).

The study area is situated in the Nampula Complex (Lächelt 2004; Thomas et al. 2011) or Nampula Block (Macey et al. 2013). Nampula complex is composed by Mesoproterozoic rocks that are classified as Mocuba Group (ca. 1,125 Ma meta-volcanic-plutonic rock assemblage), Rapale Gneiss (ca. 1,095 Ma intrusive orthogneiss), Molócuè Group (ca. 1,090 Ma supracrustal paragneiss, metavolcanic rock assemblage) and Culicui Group (ca. 1,070 Ma intrusive granitic orthogneisses) (Macey et al. 2013).

Figure 1 shows the main rocks in Rapale district representing the Mocuba (P2NMmd), Molócuè (P2NMa) and Culicui (P2NMga) groups. P2NMmd is banded biotite gneiss and migmatitic biotite gneiss with an age of $1,095 \pm 8$ $\mathrm{Ma}, \mathrm{P} 2 \mathrm{NMa}$ is a variety of gneisses (ultramafic, mafic, amphibolic and metapelitic gneiss with an age of 1,090 \pm 22 $\mathrm{Ma}$ ) and P2NMga is a variety of granitic gneiss (leucogranitic, streaky augen and augen granitic gneiss) with an age of 1,074 $\pm 26 \mathrm{Ma}$. The Marrupula Group (Monapo complex) is com-

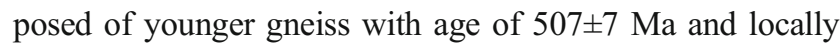
covers the Nampula complex's rocks. The hills are outcrops of rocks that resisted the erosion process, known as inselbergs. The eroded sediments were deposited in valley and plain areas covering the basement.

The Mesoproterozoic rocks have a low potential for groundwater production yielding less than $3,000 \mathrm{~L} / \mathrm{h}$ (Salomon Lda, unpublished report, 2010). The groundwater occurrence and transport is controlled by fractures, fissures and weathered zones as in all consolidated rocks. In the Rapale district, there are three subclasses of discontinuous aquifers labelled as $\mathrm{C} 1, \mathrm{C} 2$, and $\mathrm{C} 3$ (Fig. 2). In areas classified as $\mathrm{C} 1$ subclass, there are local aquifers in the weathered migmatite gneiss complex, where the yield will not exceed $5,000 \mathrm{~L} / \mathrm{h}$. C1 aquifers are mainly shallow, but they can reach about $40 \mathrm{~m}$ in depth, while $\mathrm{C} 2$ is similar to $\mathrm{C} 1$ but with less developed weathering and the thickness of aquifer reaches 20 $\mathrm{m}$ and the possible yield will not exceed 3,000 L/h. The subclass $\mathrm{C} 3$ is an aquifer with limited groundwater situated in the gneiss-complex and the expected productivity is under 1,000 L/h (Salomon Lda, unpublished report, 2010).

\section{Weathering process}

Weathering can be described as the breakdown of materials, caused by mechanical or chemical processes generated by the climate (Acworth 1987). A weathered zone can be described as a zone where rock has degraded into smaller particles such as clay, sand, gravel and stone. In tropical climates, the chemical weathering is dominant, while mechanical weathering dominates in desert and polar areas.

Figure 3 describes the subsurface of a weathered crystalline rock in tropical areas. The weathered rock can be divided into 
Fig. 1 Geology of Rapale District and the surveyed boreholes. $\mathrm{Br} 1$ Passala, $B r 2$ Cuhare B, Br3 Namitatari, Br4 Napari, Br 5 Murothone, Br6 Incomate Sae, $B r 7$ Muriaze, $B r 8$ Namachilo, $B r 9$ Matibane, $B r 10$ Naholoco comunidade, $B r 11$ Naholoco EP1, Br12 Naholoco EP2

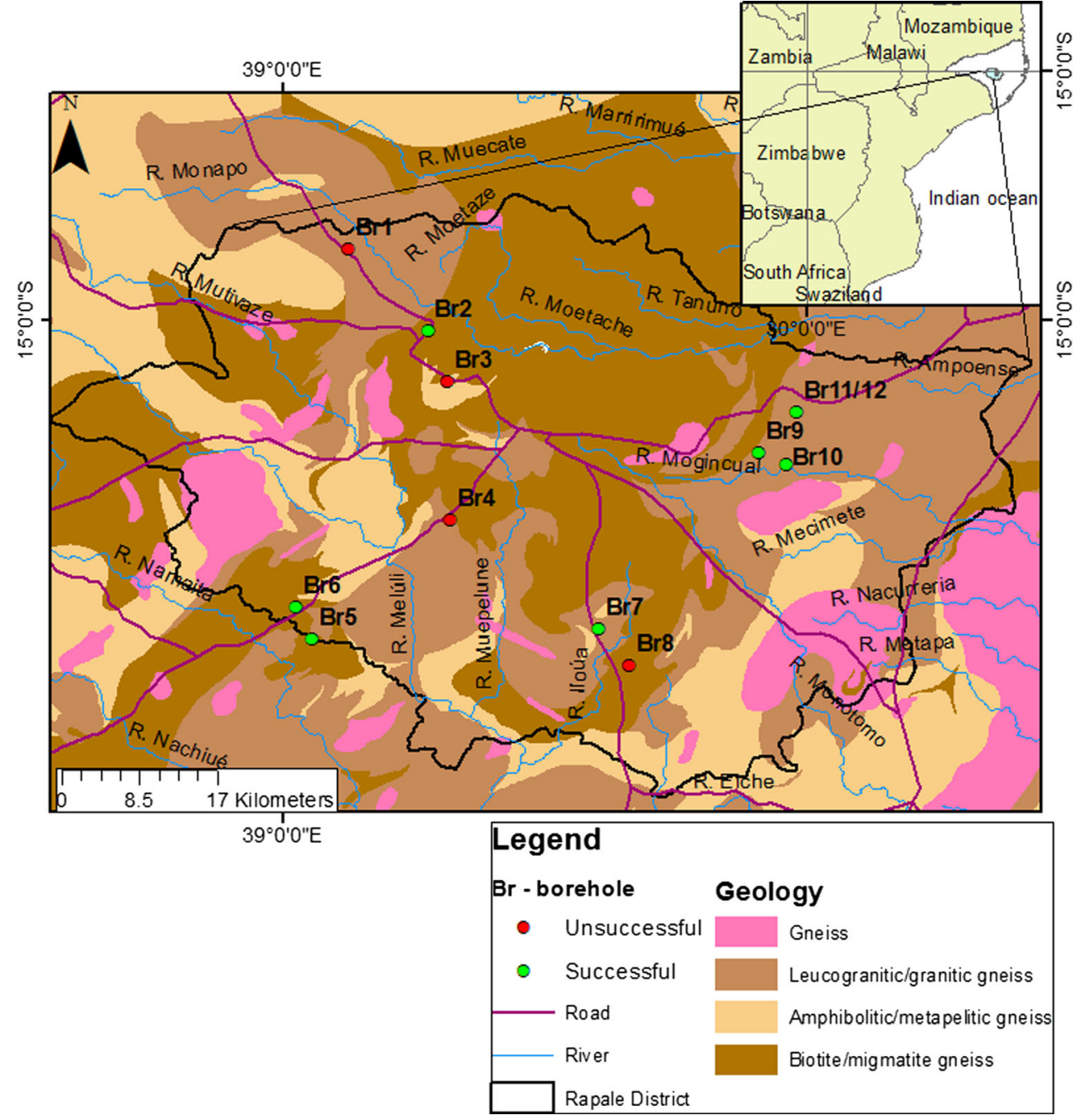

three different soil horizons (soil A, B and C) that vary in thickness and weathering degree, but not in order. Soil C can be subdivided in four zones $(\mathrm{a}-\mathrm{d})$. To contain aquifers, the weathered profile requires a certain areal extent and thickness, together with a sufficient permeability and thickness, to be able to yield groundwater to extraction points (Acworth 1987).

The most favourable condition for groundwater extraction can be found in zone c and d (Fig. 3), where the permeability is relatively high, together with high porosity. The most productive boreholes are those passing through at least $10 \mathrm{~m}$ of zone $\mathrm{c}$ and that intersects the fractures in zone $\mathrm{d}$. Zone $\mathrm{b}$ could be an aquitard or a confining layer depending on its thickness and the hydraulic conductivity. Thus if the layer $\mathrm{c}$ is overpumped, some recharge can occur from the aquitard and from fractured zone d (Acworth 1987).

\section{Well siting and vertical electrical sounding (VES)}

For the site pre-investigation carried out prior to drilling, VES was used to identify suitable borehole sites (Salomon Lda, unpublished report, 2010). At each community a committee was created that was responsible for choosing three preferential places which were based on proximity to the community. VES was carried out at these three sites and the result used as basis for selecting which of these had the best potential to supply water. If the first option was not successful then the drillers would try the second and third option. Each borehole has a report with information of drilling rate, geological logging, casing and pumping tests. The drilling reports were used as reference material for interpretation of the ERT results and in comparison with the VES. A high number of unsuccessful boreholes are related to VES option No. 1, which is the first option of the community. It is an indication that the survey was based mainly on the community's preference, and not on geological conditions.

Figure 4 shows examples of some VES models of the preinvestigation. In general, 3-4 layers were identified with VES from which the range of $20-80 \mathrm{ohm}-\mathrm{m}$ is considered to have good conditions for drilling. Resistivity below this value was considered to be caused by saline water, while above this range it was considered as having too low a yield. Srivastava 


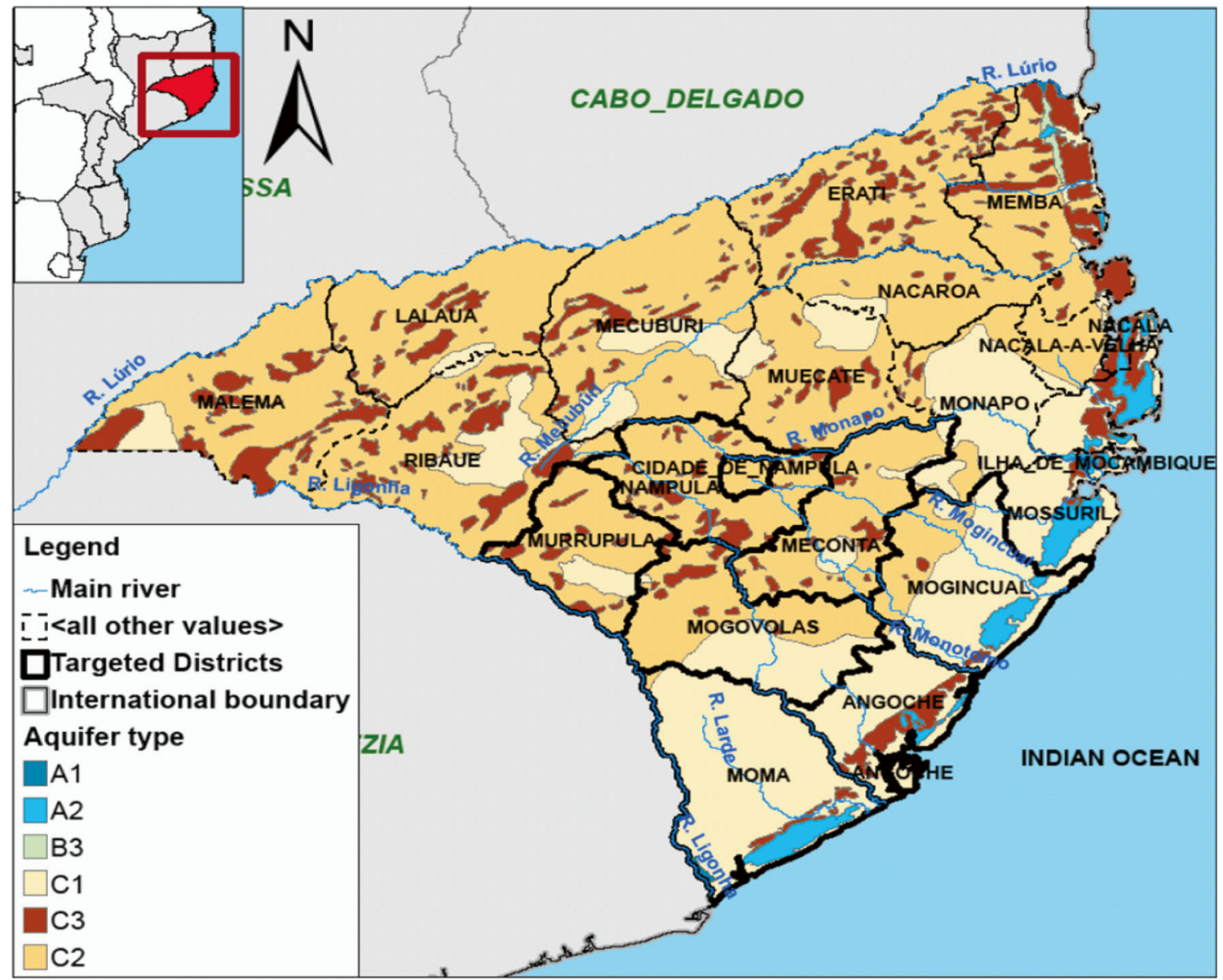

Fig. 2 Hydrogeological map of the Nampula province. Aquifer type A $(A 1, A 2$ and $A 3)$ are continuous aquifers related to unconsolidated sediments and type $\mathrm{C}(\mathrm{Cl}, \mathrm{C} 2$ and $C 3)$ are discontinuous aquifers

and Bhattacharya (2006) indicated a range of 100-300 ohm-m for weathered granite and a range of 300-600 ohm-m in related to consolidated rocks. Rapale district is within the Cidade de Nampula borders (from Salomon Lda, unpublished report, 2010)

fractured granite; in fact, Br10 (Fig. 4g) is a successful borehole with more than 80 ohm-m.
Fig. 3 A typical weathering profile describing the weathering of crystalline basement rocks (Acworth 1987)
PROFILE

DESCRIPTION

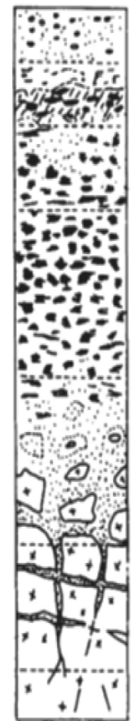

Soil 'A' horizon: generally less than $0.5 \mathrm{~m}$ thick Generally a red sandy soil, high porosity, well drained and leached Soil ' $B$ ' horizon: depositional zone with formation of laterite or calcrete. Thickness varies up to $15 \mathrm{~m}$

Zone 'a' (soil ' $C$ ' zone) few metres thick sandy clay or clay sand, often concretionary

Zone ' $b$ ': 1 to 30 m thick

Massive accumulation of secundary minerals (clays) in which some stable primary minerals may be present in their original form

Low permeability and high porosity

Zone ' $c$ ': $1 \mathrm{~m}$ to $30 \mathrm{~m}$ thick

Rock which is progressively altered upward to a granula friable layer of disintegrated crystal aggregates and rock fragments

Intermediate porosity and permeability

Zone ' $\mathrm{d}^{\prime}: 1 \mathrm{~m}$ to $20 \mathrm{~m}$ thick

Fractured and fissured rock

Low porosity but moderate to high permeability in fissures

Fresh rock

\section{PERMEABILITY POROSITY (relative) (approximate)}
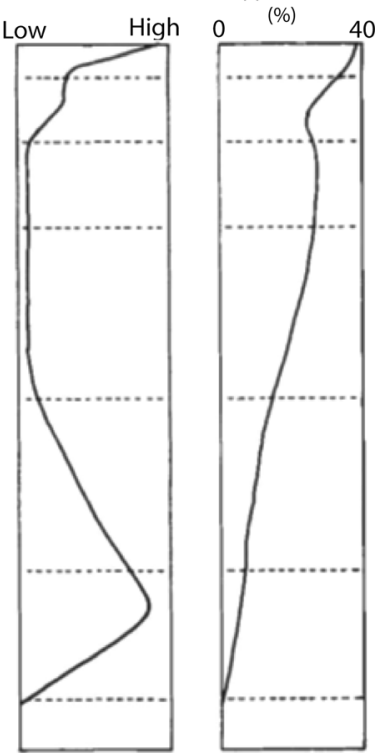
(a) $\mathrm{Br}$

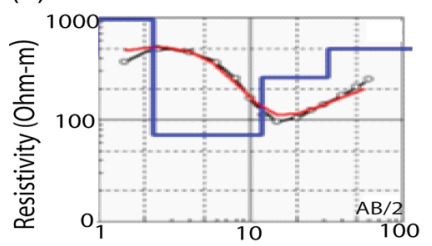

Electrode separation $(\mathrm{m})$

(c) $\mathrm{Br} 8$

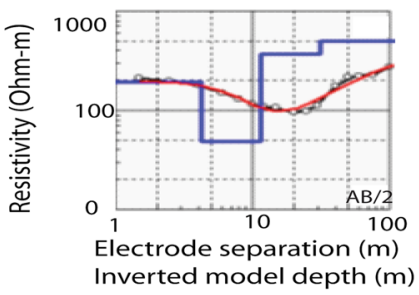

(e) $\operatorname{Br} 5$

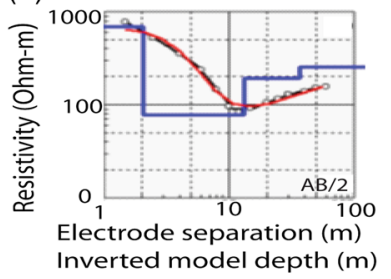

(g) $\mathrm{Br} 10$

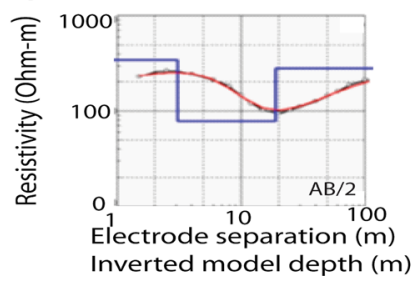

(b) $\mathrm{Br} 4$

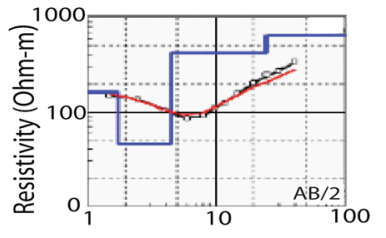

Electrode separation $(m)$ Inverted model depth ( $\mathrm{m})$

(d) $\mathrm{Br} 11$

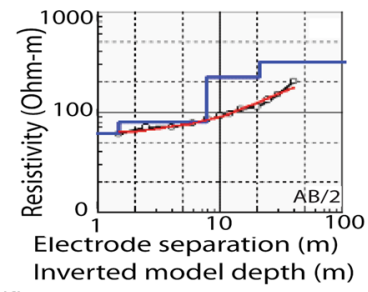

(f) $\mathrm{Brg}$

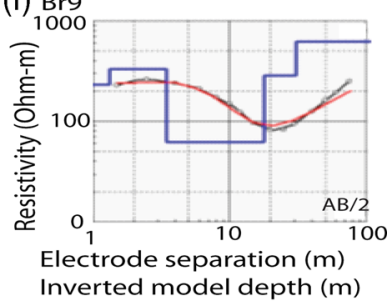

(h) $\mathrm{Br} 12$

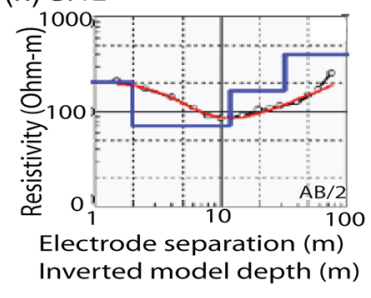

Fig. 4 Examples of VES models used to decide borehole siting (Salomon Lda, unpublished report, 2010). The circles indicate the measured values, the black line is the interpolation between the measured values, the red line is model response and the blue line is the inverted model. a-d VES here are unsuccessful boreholes, $\mathbf{e}-\mathbf{h}$ VES are successful boreholes

\section{Methodology}

\section{Borehole selection process}

In total, 12 boreholes were investigated (Fig. 1). The selection of the investigation sites was based on the yield. Five unsuccessful boreholes that have a yield less than $600 \mathrm{~L} / \mathrm{h}(\mathrm{Br} 1, \mathrm{Br} 3$, $\mathrm{Br} 4, \mathrm{Br} 8$ and $\mathrm{Br} 11$ ), and seven successful boreholes that have a yield higher than $600 \mathrm{~L} / \mathrm{h}(\mathrm{Br} 2, \mathrm{Br} 5, \mathrm{Br} 6, \mathrm{Br} 7, \mathrm{Br} 9, \mathrm{Br} 10$ and Br12) were selected. The successful boreholes were subdivided in boreholes with high yield $\mathrm{Br} 2, \mathrm{Br} 7$ and $\mathrm{Br} 12$, intermediate yield $\mathrm{Br} 5$ and $\mathrm{Br} 6$ and low yield $\mathrm{Br} 9$ and $\mathrm{Br} 10$. Also $\mathrm{Br} 12$ was selected because it is located close to $\mathrm{Br} 11$. A profile connecting these two boreholes would give a better understating of lateral variation in resistivity between successful and unsuccessful boreholes.

\section{Electrical resistivity tomography (ERT)}

The equipment used for ERT in this survey is ABEM Lund Imaging System (Dahlin 1996). The ERT technique has proved to be versatile, fast and cost effective in delineating aquifers and mapping shallow subsurface anomalies (Kumar 2012). The information retrieved with this technique is crucial in planning for the groundwater exploration.

In total, 81 electrodes separated by $5-\mathrm{m}$ spacing divided between four cables gave a spread of $400 \mathrm{~m}$. Multiple gradient arrays were used throughout as they give a suitable combination of lateral and vertical resolution, and are well suited for multi-channel measuring thus making the field work time efficient (Dahlin and Zhou 2006). Data were collected by using a system based on a Terrameter SAS4000, ES10-64C switcher and $12 \mathrm{~V}$ battery.

A perpendicular cross with two 400-m survey lines was made close to each borehole, except in a few cases where physical restrictions limited it to one line. Additionally, a longer survey line crossing $\mathrm{Br} 11$ and $\mathrm{Br} 12$ with $900 \mathrm{~m}$ in length was intersected by two perpendicular survey lines, each $400 \mathrm{~m}$ long. All data were inverted with the Res2dinv software (Loke 1999) using robust (L1 norm type) inversion. The option for grid refinement, giving model cells with half the width of the electrode spacing, was used throughout.

\section{Magnetic resonance sounding (MRS)}

Magnetic resonance sounding (MRS) measures a magnetic resonance signal generated directly from subsurface water molecules (Legchenko and Valla 2002). The NUMIS acquisition system (IRIS instruments) was used, where the NUMIS instrument is connected to a computer, batteries and an antenna.

The decay signal obtained after switching off the excitation pulse is very sensitive because it has a low amplitude, of the order of tens of nano Volts (nV) (Plata and Rubio 2002). The decay signal is easily disturbed by (1) presence of anthropogenic noise in the area, (2) ambient noise from natural sources and (3) a small signal of the earth's magnetic field that easily drowns in noise.

Electrical power lines are the main source of the anthropogenic noise. Minerals, such as pyrite and chalco-pyrite common in granite and gneiss in forms of veinlets, are the main minerals that have magnetic properties. These minerals are important factors in determining relaxation rates and surface relaxivity (Keating and Knight 2010). Both relaxation rate and surface relaxivity will have influence on the variation of phase and frequency reducing the data quality of the decay signal.

\section{Reference data}

The reference data for interpretation of the geophysical results were based on the information collected in the 
drilling reports and also the geological and lineament map. The lineament map shows the lineaments caused mainly by (1) tectonic faults, folds and fractures, (2) geomorphology features such as ridges and valleys, (3) displacement of ridge lines, scarp faces and river passages, and (4) pronounced breaks in crystalline rock masses and aligned surface depression (Sander et al. 1997; Mogaji et al. 2011). The lineaments were digitized from the geological map of the study area at a scale of 1:250,000 and classified as faults, folds and other lineaments. The drilling reports were produced for each borehole and have information about drilling rate, geological logging, water quality and pumping test results. The company that conducted the project has provided a copy of each report for this study (Salomon Lda, unpublished report, 2010).

\section{Results and interpretation}

\section{Vertical electrical sounding survey}

The pre-study in the EDNRWPI program was done basically with the VES method performed where the communities have chosen their three options. One field observation is that usually one of these three options coincides with the vicinity community leader's home. In a total of 16 unsuccessful boreholes in Rapale district, 10 are the first option of the community, 4 are the second option and 2 are the third option. Clearly the third option had given few unsuccessful boreholes.

A summary of the VES model resistivity values is presented in Table 1. The unsuccessful boreholes are marked as 'Un' and the successful as ' $\mathrm{S}$ '. Br1, Br6, Br9 and Br12 have 4 layers whereas others have only 3 . Based on the Acworth (1987) classification (Fig. 4), layer 1 is the soil or zone a with a thickness in range of $0.63-4.53 \mathrm{~m}$ and resistivity value in range of $85.6-892 \mathrm{ohm}-\mathrm{m}$. The second layer is classified as zone $b$ with a thickness in range of $1.33-20.6 \mathrm{~m}$ and resistivity value in range of 48.7-951 at Br6. The third layer is classified as zone $\mathrm{c}$ with a thickness in range of 9.56-23.6 $\mathrm{m}$ and a resistivity value in range of $62.2-543 \mathrm{ohm}-\mathrm{m}$. The fourth layer is classified as a mix of the zone $\mathrm{d}$ and the basement with a resistivity value in range of $81.7-478 \mathrm{ohm}-\mathrm{m}$.

\section{Geological lineaments results}

Over the last four decades many studies have employed lineament mapping as the core of the groundwater exploration work (Sander et al. 1997) with an important role in complex geology as in this study area. The density of lineaments intersection in the area is a good indication of groundwater presence (Mogaji et al. 2011) but fractures are often covered by the weathered layer, making them hard to detect. A limitation of this approach is the scale of the map because the geology varies significantly each meter and, by using a 1:250,000 map, one cannot locate the precise lineament position in the ground which calls for follow-up by geophysics in order to pinpoint the location of the fracture zone below the weathered layer.

The resulting map of digitized lineaments is presented in the Fig. 5. The successful boreholes $\operatorname{Br} 9, \operatorname{Br} 10$ and $\operatorname{Br} 12$ are well positioned in relation to a fault with WE direction and $\mathrm{Br}$ 7 is close to a fold. The most favourable places to site water wells is close to the end of the lineaments (Sander et al. 1997; Owen et al. 2007) which is in line with the position of all boreholes; however, $\mathrm{Br} 3$ and $\mathrm{Br} 4$ are unsuccessful boreholes located close to the end of the lineaments.

\section{Electrical resistivity tomography results}

The ERT data were generally of good quality and the inversions resulted in good model fit with small deviations between model responses and measured data. The mean residual of all profiles ranged between 1.3 and $4.8 \%$ except in $\mathrm{Br} 5$ with $15.4 \%$ mean residual.

\section{Successful boreholes surveyed}

Figure 6 shows two examples out of several where lowresistivity layers match with productive wells (Br12 and Br10) and a high-resistivity layer matches with an unsuccessful well (Br11). Both sites show intermediate values of resistivity at the subsurface, followed by a low-resistivity layer and a high-resistivity layer at the bottom, respectively numbered as layers 1, 2 and 3 (Fig. 6).

The ERT model between Br11 and BR12 starts with a thin layer (1) at the surface, with intermediate resistivity values $(220-770 \mathrm{ohm}-\mathrm{m})$ to an approximate depth of about $0-5 \mathrm{~m}$ (Fig. 6a). Layer 2 has a low resistivity value (10-220 ohm-m) and thickness of 5-35 m (Fig. 6a), which could represent weathered to moderately weathered rock material or zone c (Fig. 3). Layer 3 has relatively a high resistivity value $(>120 \mathrm{ohm}-\mathrm{m})$ representing P2NMga lithology (Fig. 1). The lateral variation of thickness of the layer 2 explains the success at Br12 and lack of success at Br11. Figure $6 \mathrm{~b}$ shows an ERT model of Br10 with slightly low resistivity values for layer 3 when compared with the ERT model of Fig. 6a. This layer is interpreted as weathered layer or zones $\mathrm{c}$ and $\mathrm{d}$. As indicated by geological borehole logging, the basement was not reached. The interpretation of VES for Br10 and Br11/Br12 (Fig. 4g,d,h) indicated three resistivity layers. In $\mathrm{Br} 12$, the drilling stopped at depth of 35 meters where the resistivity value is $70.6 \mathrm{ohm}-\mathrm{m}$ (Fig. $4 \mathrm{~h}$ ), which is in the range of layer 2 (Fig. 6a). The VES of Br10 also 
Table 1 Summary of the VES model resistivities and their corresponding thickness (Salomon Lda, unpublished report, 2010). Un unsuccessful; $S$ successful

\begin{tabular}{|c|c|c|c|c|c|c|c|c|c|}
\hline \multirow[t]{2}{*}{ VES } & \multirow{2}{*}{$\begin{array}{l}\text { Borehole } \\
\text { outcome }\end{array}$} & \multicolumn{2}{|l|}{ First layer } & \multicolumn{2}{|c|}{ Second layer } & \multicolumn{2}{|l|}{ Third layer } & \multicolumn{2}{|c|}{ Fourth layer } \\
\hline & & $\begin{array}{l}\text { Resistivity } \\
\text { (ohm-m) }\end{array}$ & $\begin{array}{l}\text { Thickness } \\
\text { (m) }\end{array}$ & $\begin{array}{l}\text { Resistivity } \\
\text { (ohm-m) }\end{array}$ & $\begin{array}{l}\text { Thickness } \\
\text { (m) }\end{array}$ & $\begin{array}{l}\text { Resistivity } \\
\text { (ohm-m) }\end{array}$ & $\begin{array}{l}\text { Thickness } \\
\text { (m) }\end{array}$ & $\begin{array}{l}\text { Resistivity } \\
\text { (ohm-m) }\end{array}$ & $\begin{array}{l}\text { Thickness } \\
\text { (m) }\end{array}$ \\
\hline $\mathrm{Br} 1$ & Un & 417 & 0.96 & 951 & 1.33 & 71.1 & 9.56 & 261 & 20.3 \\
\hline $\mathrm{Br} 2$ & S & 892 & 3.48 & 61.2 & 16.5 & 143 & 18.2 & - & - \\
\hline $\mathrm{Br} 3$ & Un & 189 & 2.44 & 85.6 & 20.6 & 186 & 14.2 & - & - \\
\hline $\mathrm{Br} 4$ & Un & 293 & 1.5 & 138 & 11.4 & 543 & 19.3 & - & - \\
\hline $\mathrm{Br} 5$ & $\mathrm{~S}$ & 689 & 2.06 & 77.4 & 11.2 & 192 & 23.6 & - & - \\
\hline Br6 & $\mathrm{S}$ & 114 & 0.63 & 357 & 1.41 & 38.7 & 19.1 & 81.7 & 12.5 \\
\hline $\mathrm{Br} 7$ & S & 196 & 4.53 & 55.6 & 13 & 123 & 16 & - & - \\
\hline $\mathrm{Br} 8$ & Un & 193 & 4.22 & 48.7 & 7.19 & 365 & 20.2 & - & - \\
\hline $\mathrm{Br} 9$ & $\mathrm{~S}$ & 231 & 1.32 & 332 & 2.14 & 62.2 & 14.5 & 285 & 12.6 \\
\hline $\operatorname{Br} 10$ & S & 207 & 0.88 & 343 & 2.2 & 78.5 & 16 & - & - \\
\hline Br11 & Un & 205 & 1.98 & 70.6 & 9.85 & 167 & 20.2 & - & - \\
\hline Br12 & $\mathrm{S}$ & 85.6 & 0.76 & 219 & 1.45 & 90.2 & 18 & 478 & 24.1 \\
\hline
\end{tabular}

indicated 3 layers and the resistivity of $78.5 \mathrm{ohm}-\mathrm{m}$ (Fig. 4g), which is out of the range indicated in Fig. 6b (220-420 ohm-m).

\section{Unsuccessful boreholes surveyed}

When the layer 2 is not well developed and the basement is close to surface, a successful borehole is very unlikely. That is shown in the Fig. 7 where the layer 2 has a thickness of $10 \mathrm{~m}$ at $\mathrm{Br} 4$ and less in Br1 (Fig. 7b). From the ERT model of Br4 (Fig. 7a) the layer 1 is discontinuous with resistivity in the range of 220-770 ohm-m and thickness 10-12 m, the layer 2 is a continuous layer with intermediate resistivity in range of
19-220 ohm-m, and layer 3 has a resistivity value higher than 770 ohm-m. Br1 (Fig. 7b) also shows 3 different layers. The layer 1 is discontinuous with resistivity in range of 220-1400 ohm-m and thickness less than $10 \mathrm{~m}$, the layer 2 is a continuous layer with intermediate resistivity in the range of 19-420 ohm-m, and layer 3 has a resistivity value higher than 770 ohm-m. The description of the borehole indicates that the layer 1 is dry sand and soil, the layer 2 is composed by clay, and layer 3 is granitic fresh rock. The description of weathered granite does not match with the ERT model .

In the $\mathrm{Br} 4$ model, layer 2 has good conditions for siting a borehole from 0 to $100 \mathrm{~m}$ and from 200 to $300 \mathrm{~m}$ (towards the east) due to development of the weathered layer. By using the
Fig. 5 Different lineaments at Rapale district and the position of both successful and unsuccessful borehole (adapted from Macey et al. 2006)

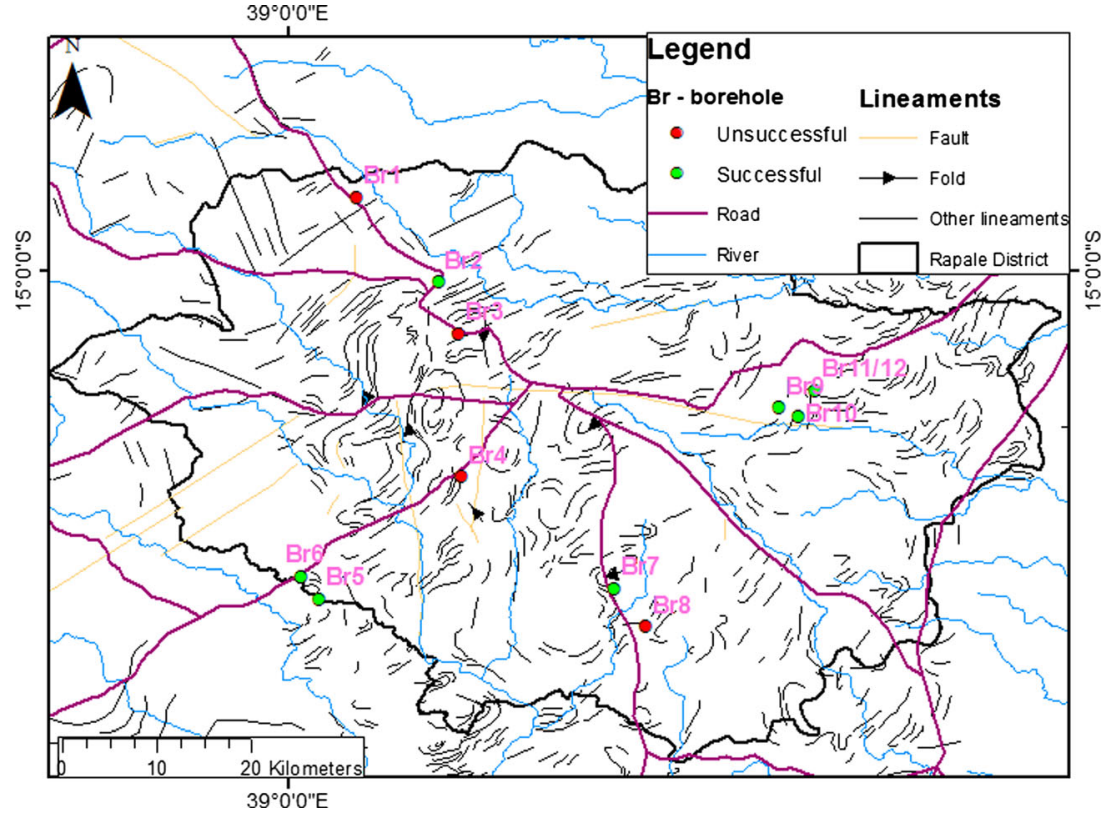


Fig. 6 ERT model of two sites at a $\mathrm{Br} 11 / \mathrm{Br} 12$ and $\mathbf{b} \mathrm{BR} 10$. The numbers 1,2 and 3 indicate the different geophysical layers. The length and depth scales in $6 . \mathbf{a}$ are given in meters

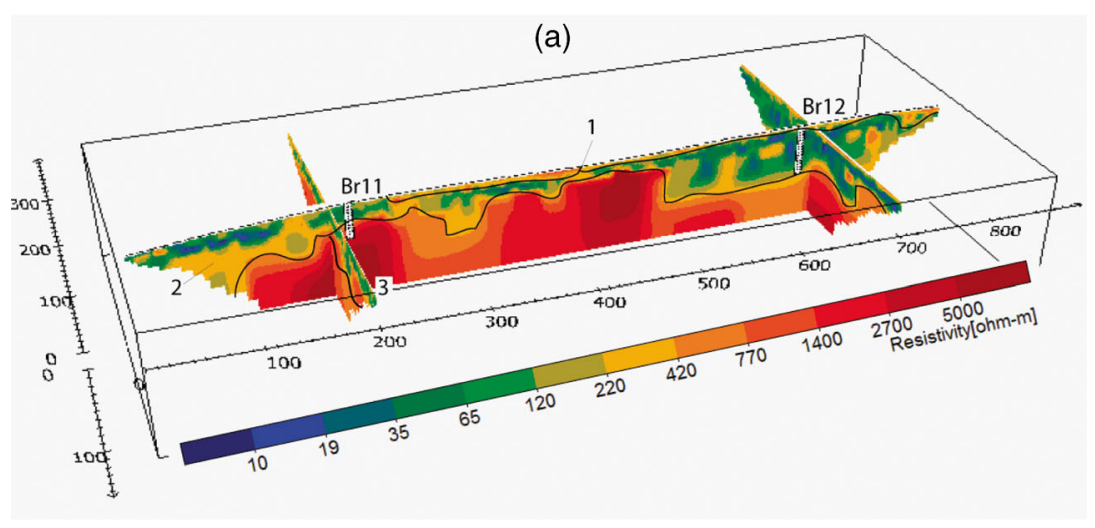

(b)

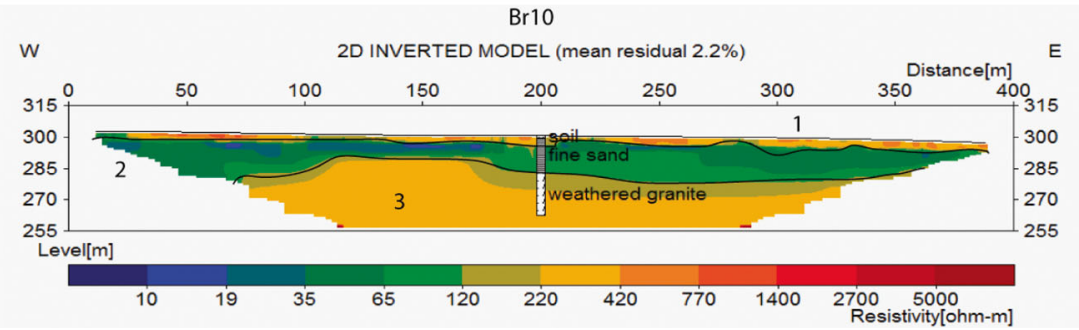

ERT method these areas could have been indicated as having potential to site a water well. Both VES (Fig. 4a,b) indicate that although the resistivity value is in range for a potential borehole siting, the thickness of this second layer is too thin (Table 1) to be considered as productive.

\section{Exceptions to the expected geophysical models}

Exceptions to the expected geophysical models are presented below; they display successful wells in areas where the geophysics would not lead to expectations of such wells.
Fig. 7 ERT models of unsuccessful boreholes: a the model at $\mathrm{Br} 4$ and $\mathbf{b}$ the model at $\mathrm{Br} 1$

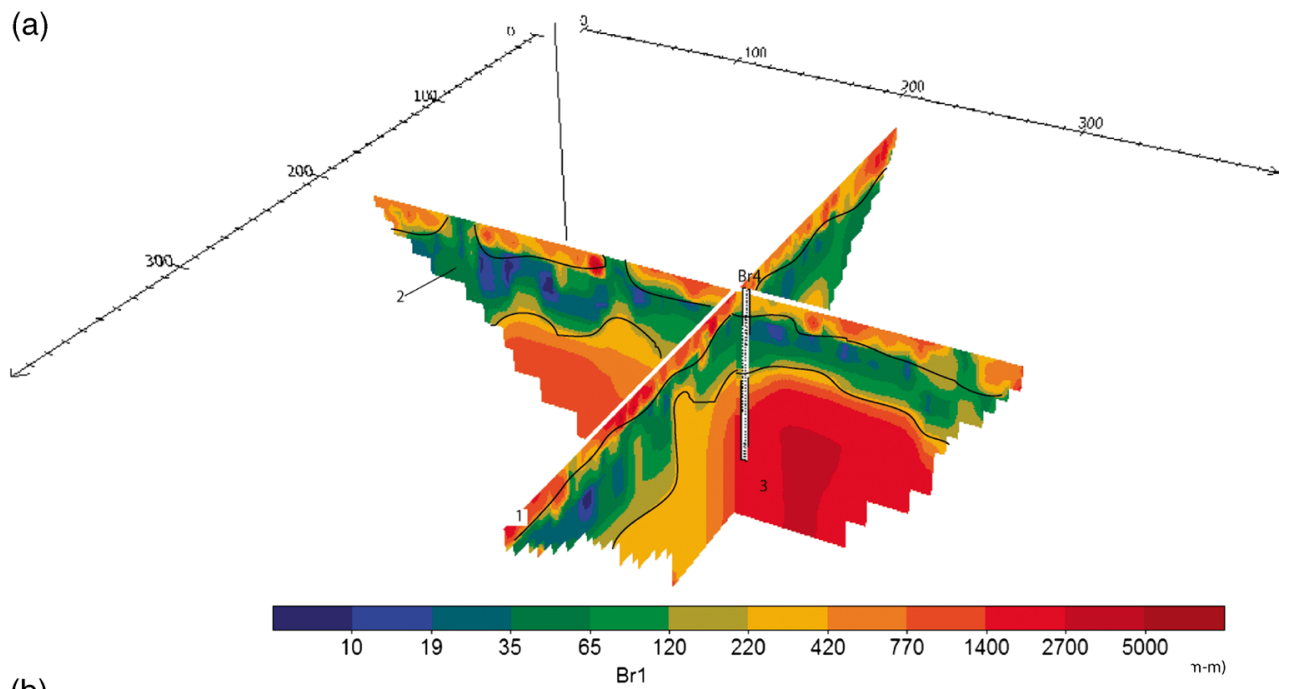

(b) $\mathrm{w}$

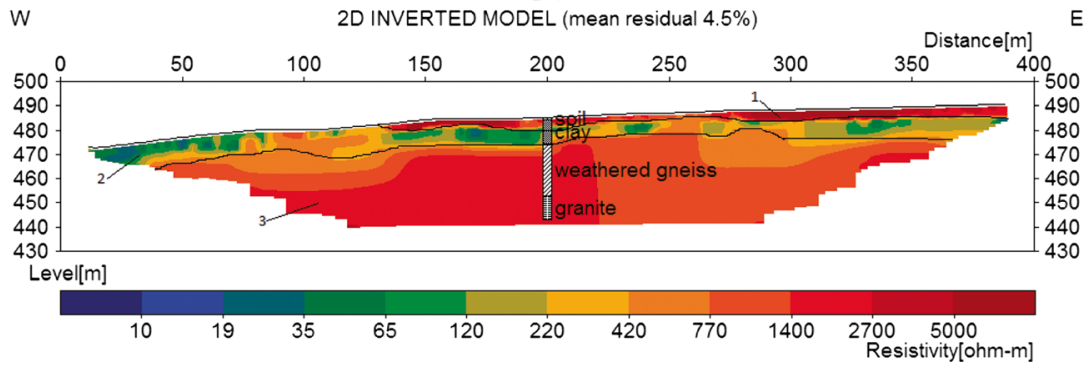


The borehole in Br8 is located in a zone with lineaments (Fig. 5) suggesting good conditions for a successful borehole but it turned out an unsuccessful one. Although the layer 2 is $20 \mathrm{~m}$ thick (Fig. 8a), the layer 3 has a low resistive value that is interpreted as highly fractured and therefore a potential site for drilling. The resulting models at $\mathrm{Br} 5$ and $\mathrm{Br} 9$ suggest unsuccessful boreholes due to a high resistive layer 3 and a thin layer 2 (Fig. 8b,c). In these two communities, the obtained models are similar to the unsuccessful borehole model $\mathrm{Br} 4$ (Fig. 7). However, they have a good yield and were considered as successful boreholes. As no lineaments were detected close to both boreholes (Fig. 5), a reasonable explanation would be that layer 3 (zone $d$ in Fig. 2) has open fractures that increase the transmissivity. Possibly the fractures act as pathways for groundwater from surrounding zones with high porosity; however, the ERT cannot resolve relatively narrow fractures.

\section{Magnetic resonance sounding (MRS)}

MRS was performed at Br5 and Br6 (Fig. 1), where the earth magnetic field and primary porosity were small resulting in a weak signal from the water molecules. The measured magnetic field caused by solar radiation in the study area was 5,000 $\mathrm{nV}$. This value is by far higher than the expected value of around 1,500 $\mathrm{nV}$ in this part of the world (Plata and Rubio; 2002), and it is too high to allow the measurement of good quality data over aquifers in granite and gneiss. The antenna loop was laid out in two different ways in attempts to improve the quality of measurements: square loop $(100 \times 100 \mathrm{~m})$ and figure-of-eight loop ( 2 squares of $50 \times 50 \mathrm{~m}$ each) respectively; however, the quality of data was not good enough to detect the decay signal pattern.

\section{Geological setting for surveyed sites}

Table 2 summarizes all the surveyed boreholes in terms of geology, yield and drilled depth. The geology is based on the map of Figs. 5 and 1, and the yield values were obtained from the drilling report of each borehole. The boreholes at $\mathrm{Br} 1, \mathrm{Br} 3$, $\mathrm{Br} 4, \mathrm{Br} 8$ and Br11 were dry and have no yield (less than 600 $\mathrm{L} / \mathrm{h}$ ) and therefore were interpreted as situated in a possible aquitard. Due to low yield $(600 \mathrm{~L} / \mathrm{h})$, the boreholes $\mathrm{Br} 9$ and Br10 were interpreted as situated in a possible aquitard, while $\mathrm{Br} 2, \mathrm{Br} 5, \mathrm{Br} 7, \mathrm{Br} 9$ and $\mathrm{Br} 12$ were interpreted as situated in aquifers due to the high yield (more than $900 \mathrm{~L} / \mathrm{h}$ ).

\section{Discussion}

The task of siting a borehole for water extraction in consolidated rock areas is challenging and a proper approach should be considered. This study considered both social and technical issues that would lower the failure rate. Community participation in water-well siting has been proposed in water and sanitation projects (Glicken 2000) where the community should interactively participate throughout the process. This approach can improve results, since all proposed activities and
Fig. 8 ERT result of successful and unsuccessful boreholes in three different communities: a represents an unsuccessful borehole; $\mathbf{b}-\mathbf{c}$ represent successful boreholes
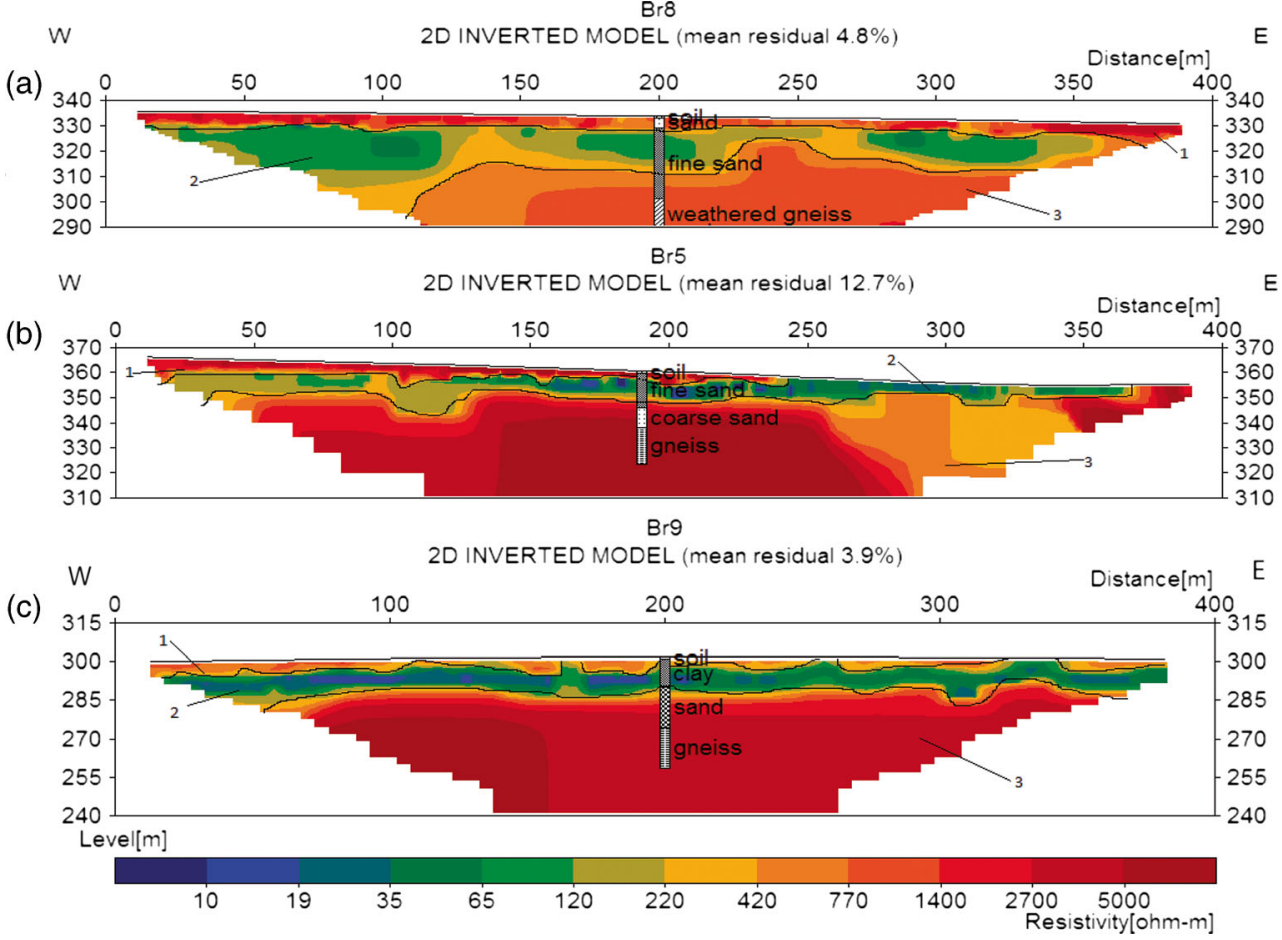
Table 2 Geological and hydrogeological classification of each surveyed boreholes in Rapale District

\begin{tabular}{|c|c|c|c|c|c|c|}
\hline Group & Symbol & Rock type & Borehole & Yield (1/h) & Drilling depth (m) & $\begin{array}{l}\text { Hydrogeological } \\
\text { classification }\end{array}$ \\
\hline \multirow[t]{8}{*}{ Culicui } & \multirow[t]{4}{*}{ P2Nmga } & \multirow[t]{4}{*}{ Augen gneiss, with charnockite } & $\mathrm{Br} 1$ & No yield & 47.75 & Aquitard \\
\hline & & & $\mathrm{Br} 9$ & 600 & 47.65 & Aquitard \\
\hline & & & Br11 & No yield & 29.4 & Aquitard \\
\hline & & & $\operatorname{Br} 12$ & 1,960 & 45.42 & Aquifer \\
\hline & \multirow[t]{4}{*}{ P2Nmal } & \multirow[t]{4}{*}{ Streaky augen leocogranitic gneiss } & $\mathrm{Br} 4$ & No yield & 44.99 & Aquitard \\
\hline & & & $\operatorname{Br} 5$ & 1,200 & 38.44 & Aquifer \\
\hline & & & $\mathrm{Br} 7$ & 5,300 & 33.76 & Aquifer \\
\hline & & & $\operatorname{Br} 10$ & 600 & 38.61 & Aquitard \\
\hline \multirow[t]{4}{*}{ Mocuba } & \multirow[t]{3}{*}{ P2NMmd } & \multirow[t]{3}{*}{ Hornblende-bearing granodioritic gneiss } & $\mathrm{Br} 2$ & 1,920 & 45.9 & Aquifer \\
\hline & & & Br6 & 998 & 30.17 & Aquifer \\
\hline & & & $\mathrm{Br} 8$ & No yield & 38.46 & Aquitard \\
\hline & $\mathrm{P} 2 \mathrm{NMa}$ & Amphibole, mafic gneiss & $\mathrm{Br} 3$ & No yield & 26.5 & Aquitard \\
\hline
\end{tabular}

outcomes are well aligned with community's expectations. Although the results of this process are generally appropriate and sustainable, it is not a simple task. The effective participation is difficult to plan, implement and develop throughout the project (Juan et al. 2002). Many unsuccessful boreholes are related to the first option of the community, which often coincides with the community leader's house. The leaders have influenced the siting of the well close of their house aiming to control it. Using an alternative, scientific based, approach would most likely increase the success in groundwater-well siting, e.g. producing a map with indication of potential areas for siting boreholes based on results of pre-investigation and presented to the community to choose preferred sites.

VES was the geophysical method used in the well drilling project to assess if places selected by the communities had favourable conditions for drilling (Salomon Lda, unpublished report, 2010). The VES site selection was thus not based on geological criteria, which may have significant consequences for the outcome. The VES results did not give the precise depth to drill, therefore, all the unsuccessful boreholes were drilled to large depth when compared with the successful borehole except Br3. Probably the extra drilled depth is in attempt to find water; however, it has economic consequences because the driller is paid for each drilled meter.

By performing an ERT measurement that gives information of lateral variation around the drilled well, it was possible to detect, in several cases, the reasons for failure. The one obvious reason is the presence of high-resistivity zones that are caused by solid rock close to surface as shown in Figs. 6 and 7. Figure 6 illustrates well the difference in thickness and resistivity values of the boreholes at Br11 and Br12. The resistivity values of these resistive zones are higher than $220 \mathrm{ohm}-\mathrm{m}$, which is in accordance with Owen et al. (2005) for granite rocks.

The interpretations of the resistivity values were based on the work of Palacky (1987), Acworth (2001) and
Muchingami et al. (2012). As many common earth materials span large resistivity value spectra that overlap, and there are uncertainties on how well the interpretation of the results reflects reality; therefore additional information was used to improve the interpretation. Hydrogeological, geological and lineament maps were used as a base for plausible interpretation of the geophysical results in this study. The result is that granite and gneisses from Nampula block are the basement rocks in the study area.

The thickness of the weathered layer varies significantly at each borehole site but not the resistivity value, which is in range of 19-220 ohm-m. The ERT method could not resolve the precise limit of the weathered layer because the change is gradual. The variation of the resistivity values, from a high resistivity value of fresh rock to low values due to saturation with groundwater or presence of clay layer, was the only way to infer the lower limit. Available information about fractures and faults are on a regional scale, which makes it more difficult to assess the role of these factors and a mapping campaign at local scale would give more information to understand their role in groundwater occurrence. However, in some communities (Fig. 7) the groundwater is strongly controlled by the fractures and other lineaments.

The geophysical layers 2 and 3, in successful boreholes, are considered as unconfined aquifers. The layer 2 is the weathered zone, labelled as c according to Acworth (1987; Fig. 3) and layer 3 is the fractured zone labelled as d (Fig. 4). Due to low yield of Br9 and Br10 (Table 2), the geophysical layer 3 was interpreted as an aquitard. The spatial variation of these two productive units and the aquitard of Mocube Group is in accordance with the model described by Acworth (2001) that varies in 3D in terms of thickness and also the variation of its resistivity value.

Figure 9 shows the main features controlling the thickness of the main hydrogeological units in the study area. Faults and 
Fig. 9 The conceptual model illustrating the optimal location to site a water well (borehole 1) and an unfavourable place (borehole 2). Layer 1 is the upper layer (soil A and soil B), layer 2 is the soil C, and layer 3 is the fresh rock

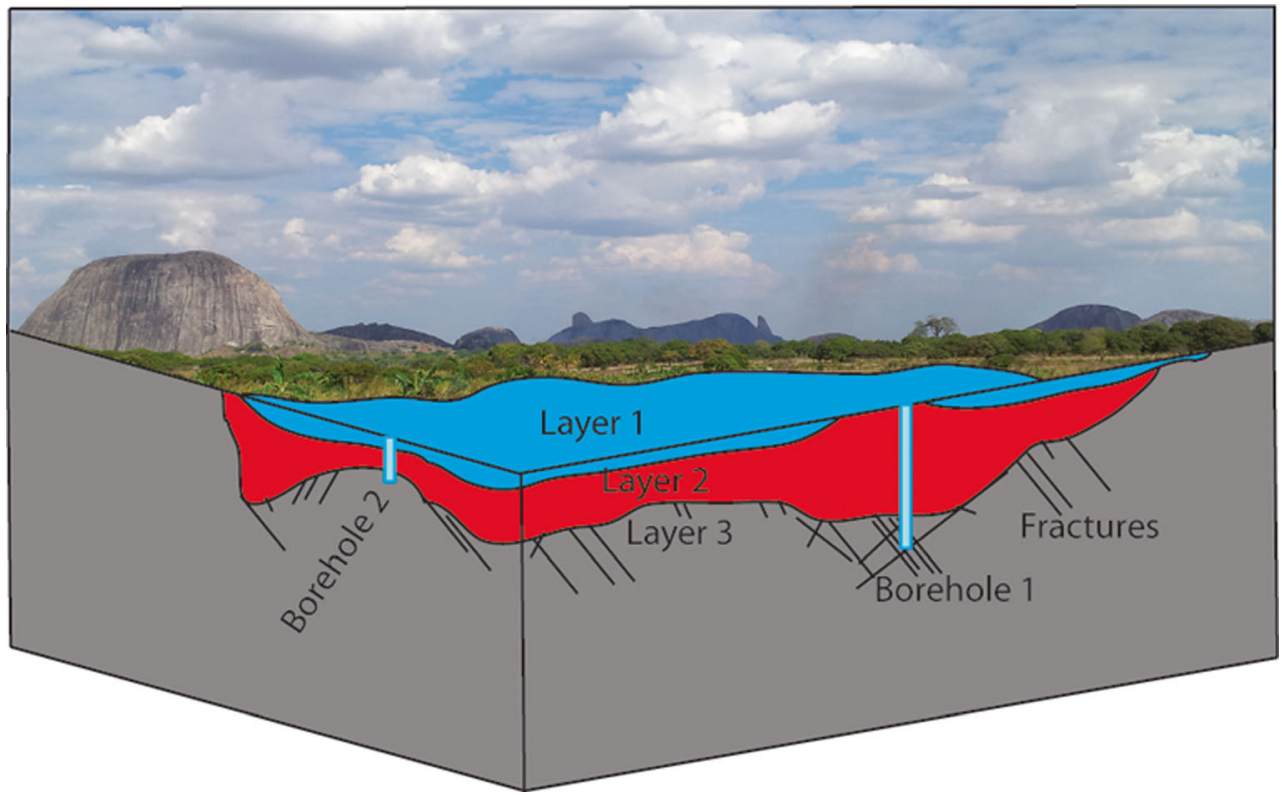

proximity to rock outcrops and the degree of weathering are the main factors controlling the groundwater occurrence. The larger the thickness of the weathered material or the more highly fractured the zone is, the more favourable it is to site a borehole there.

Several of the dry boreholes are placed on or just at the edge of the fresh rock. It is likely that if an ERT survey had been made instead of VES such a placement could have been avoided due to more comprehensive information on the $3 \mathrm{D}$ character of the geology: however, there are some successful boreholes placed on high resistive zones. The resistivity values suggest the boreholes may have intersected a fractured zone that is too small to be resolved by the ERT. The site at $\mathrm{Br} 4$ (Fig. 7a) is a good example of importance of use of ERT because it indicates that in the first $100 \mathrm{~m}$ of the profile there are good conditions to site a borehole.

The reason for successful/unsuccessful boreholes could possibly have been explained with MRS results with an indication of the amount of free water molecules in a specific site; however, the method did not work because the MRS signal-to-noise ratio (Perttu et al. 2011) was too low. The low signal level was caused by low intensity of earth magnetic field and low porosity of the unweathered rock; furthermore, the variation of magnetic field due to variation of rock properties gave a variation of the signal within the loop. The high noise level is mainly due to solar radiation (Vouillamoz et al. 2007). It can also be noted that even if the signal-to-noise levels would have more favourable, the results could have been difficult to interpret due to the strong lateral variation in aquifer properties shown by the ERT results.

There are some uncertainties in this study because of limited access to relevant reference data and uncertainty in the available reference data; however, it has been shown that a scientific approach including a conceptual geological model, comprising tectonic setting and weathering pattern, followed by ERT would improve the outcomes of the project. The CDNRWPI program drilled a total of 271 boreholes in Nampula province with a failure rate of $33 \%$. The mean drilled depth is $40 \mathrm{~m}$. The installation and removal, drilling operations and borehole construction costs, give approximately a rate of USD 100 per drilled meter. In total, around USD 4,000 was paid for each unsuccessful borehole, which is equivalent to a cost of USD 356,000 for all 89 unsuccessful boreholes. Even if taking into account the difference in cost for using a scientific approach and carrying out ERT instead of VES, the total cost is likely to be substantially reduced.

\section{Conclusion}

The geological structure of the investigated area is geometrically complex with vertical and lateral variations that can better be described by the ERT method compared to VES. The use of ERT could likely lower the failure rate of water wells if applied with a scientific approach and not using the community preference as base for where to do the investigation. MRS was tested but did not yield any useful results due to a combination of low signal levels, high noise levels and a laterally varying magnetic field.

The variation of resistivity values are in accordance with what can be expected from the local geology (granite and gneiss of Nampula complex) and resistivity values of different rock materials. The variation decreases from the surface downward crossing the zone with low permeability consisting of clay 
and clayey materials and then increases from this zone down to the fresh rock where the highest values were recorded.

Two significant hydrogeological units were identified: one altered zone with disintegrated rock fragments characterized by intermediate porosity and permeability, and the fractured zone with low porosity and high permeability. The spatial variation of the units is controlled by the proximity to the unweathered basement, presence of faults and fractures, and the degree of weathering process. There is no direct relationship between rock type and the yield, which means that the thickness of the aquifer and the occurrence of open fractures are the most important factors.

The decision of the community members in siting borehole has to be based on a conceptual geological model and geophysical information that indicates potential areas for siting a borehole. This approach would reduce the influence of the leaders and reduce the failure rate as well. The potential areas for siting a borehole should be identified based on ERT surveys due to the complexity of the geology of the area. It is also recommended to perform geophysical borehole logging to collect information that can improve the interpretation of hydrogeological conditions.

Acknowledgements We would like to thank Cowater International Inc. and Salomon Lda for technical and logistical help for supporting the survey. We also would like to thank Eduardo Mondlane staff for all kinds of support during the survey and the (MFS) Minor Field Study students Erik Sjöstrand and Oskar Enkel. Furthermore we gratefully acknowledge that SIDA has funded the study as part of the bilateral cooperation framework between Eduardo Mondlane University (UEM) and Sweden. We acknowledge that Nils Perttu was responsible for the MRS field tests and ensured that these were made according to highest technical and scientific standards, and wish to thank him for the good cooperation.

Open Access This article is distributed under the terms of the Creative Commons Attribution 4.0 International License (http:// creativecommons.org/licenses/by/4.0/), which permits unrestricted use, distribution, and reproduction in any medium, provided you give appropriate credit to the original author(s) and the source, provide a link to the Creative Commons license, and indicate if changes were made.

\section{References}

Acworth I (1987) The development of crystalline basement aquifers in a tropical environment. Q J Eng Geol Hydrogeol 20:265-272

Acworth I (2001) The electrical image method compared with resistivity sounding and electromagnetic profiling for investigation in areas of complex geology: a case study from groundwater investigation in a weathered crystalline rock environment. Explor Geophys J 32:119-128

Clark L (1985) Groundwater abstraction from basement complex areas in Africa. Q J Eng Geol Hydrog 18:25-34

Dahlin T (1996) 2D resistivity surveying for environmental and engineering applications. First Break 14(7):275-283

Dahlin T, Zhou B (2006) Multiple-gradient array measurements for multichannel 2D resistivity imaging. Near Surface Geophys J 4:113-123

Glicken J (2000) Getting stakeholder participation 'right': a discussion of participatory processes and possible pitfalls. Environ Sci Policy 3: 305-310
Juan D, Gomez A, Afamia C (2002) Community participation in water and sanitation. Water Int 27(3):343-353

Kellett R, Steensma G, Bauman P (2004) Mapping groundwater in regolith and fractured bedrock using ground and airborne geophysics: case studies from Malawi and Brazil. In: Integrated exploration in a changing world; 17th ASEG-PESA geophysical conference and exhibition; extended abstracts. Australian Society of Exploration Geophysicists Petroleum Exploration Society of Australia, Sydney

Keating K, Knight R (2010) A laboratory study of the effect of Fe(II) bearing minerals on nuclear magnetic resonance (NMR) relaxation measurements. Geophys J 75(3):71-82

Kumar D (2012) Efficacy of electrical resistivity tomography technique in mapping shallow subsurface anomaly. J Geol Soc India 80:304-307

Kumar D, Ahmed S, Krishnamurthy NS, Dewandel B (2007) Reducing ambiguities in vertical electrical sounding interpretation. J Appl Geophys 62:16-32

Lächelt R (2004) Geology and mineral resources of Mozambique. DGN, Maputo, Mozambique, $515 \mathrm{pp}$

Legchenko A, Valla P (2002) A review of the basic principles for proton magnetic resonance sounding measurements. J Appl Geophys 50:3-19

Loke MH (1999) Res2dinv ver. 3.4 for Windows 3.1, 95 and NT. Rapid 2-D resistivity and IP inversion using the least squares method. Software manual. http://www.abem.se. Assessed April 2016

Macdonald A, Calowb RC (2009) Developing groundwater for secure rural water supplies in Africa. Desalination 248:546-556

Macey P, Ingram BA, Cronwright MS, Botha GA, Roberts MR, Grantham GH, de Koks GS, Maré LP, Botha PMW, Kota M, Opperman R, Haddon IG, Nolte JC and Rower M (2006) Map explanation: sheets $1537,1538,1539,1540,1637,1638$ and 1639-40 scale 1:250,000. Council of Geoscience, Pretoria, South Africa

Macey P, Miller J, Rowe C, Grantham G, Siegfried P, Armstrong R, Kemp J, Bacalu J (2013) Geology of the Monapo Klippe, NE Mozambique and its significance for assembly of central Gondwana. Precambrian Res 233:259-281

Mogaji KA, Aboyeji OS, Omosuyi GO (2011) Mapping of lineaments for groundwater targeting in basement complex area of Ondo State using remote sensing and geographic information system (GIS) techniques. Int J Water Resour Environ Eng 3(7):150-160

Muchingami I, Hlatywayo DJ, Nel JM, Chuma C (2012) Electrical resistivity survey for groundwater investigations and shallow subsurface evaluation of the basaltic-greenstone formation of the urban Bulawayo aquifer. Phys Chem Earth 50-52:44-51

Owen R, Gwavava O, Gwaze P (2005) Multi-electrode resistivity survey for groundwater exploration in the Harare greenstone belt, Zimbabwe. Hydrogeol J 14:8

Owen R, Maziti A, Dahlin T (2007) The relationship between regional stress field, fracture orientation and depth of weathering and implications for groundwater prospecting in crystalline rocks. Hydrogeol J 15:1231-1238

Palacky G (1987) Resistivity characteristics of geological targets. In: Nabighian M (ed) Electromagnetic methods in applied geophysics, vol 1. Soc. Explor. Geophysicists, Tulsa, OK, 55 pp

Perttu N, Wattanasen K, Phommasone K, Elming S (2011) Characterization of aquifers in Vientiane Basin, Laos, using magnetic resonance sounding and vertical electrical sounding. J Appl Geophys 73(3):207-220

Plata J, Rubio F (2002) MRS experiments in a noisy area of a detrital aquifer in the south of Spain. J Appl Geophys 50:83-94

Sander P, Minor TB, Chesley MM (1997) Groundwater exploration based on lineaments analysis and reproductibility tests. Groundwater J 35(5):888-894

Srivastava PK, Bhattacharya AK (2006) Groundwater assessment through an integrated approach using remote sensing, GIS and resistivity techniques: a case study from a hard rock terrain. Int J Remote Sensing 27(20):4599-4620 
Shemang EM, Chaoka TR (2003) Two-dimensional electrical resistivity study of the basement aquifers of the Moshupa Wellfield area, Botswana. J Environ Eng Geophys 8:179-186

Thomas RJ, Ueda KM, Jacobs J, Matola R (2011) Late tectonic evolution of the Nampula Complex, NE Mozambique. In: 23rd Colloquium of
African Geology, Johannesburg, South Africa, 8-14 Jan 2011, Geological Society of Africa, Addis Ababa, 395 pp

Vouillamoz JM, Baltassar JM, Girard JF, Plata J, Legchenko A (2007)

Hydrogeological experience in the use of MRS. Bol Geol Min 118(3):531-550 